\title{
Immunomagnetic isolation of live and preserved Alexandrium fundyense cells: species-specific physiological, chemical, and isotopic analyses
}

\author{
Angeles Aguilera' ${ }^{1}$, Bruce A. Keafer ${ }^{2}$, G. H. Rau ${ }^{3}$, Donald M. Anderson ${ }^{2, *}$ \\ ${ }^{1}$ Facultad de Biología, Universidad Autónoma, Canto Blanco, 28949 Madrid, Spain \\ ${ }^{2}$ Biology Department, Woods Hole Oceanographic Institution, Woods Hole, Massachusetts 02543, USA \\ ${ }^{3}$ Institute of Marine Sciences, University of California, Santa Cruz, California 95064, USA
}

\begin{abstract}
A method to isolate cells of the toxic dinoflagellate Alexandrium fundyense from seawater samples using magnetic beads was evaluated to determine whether it could be used to obtain species-specific physiological measurements. Two isolation procedures were tested. The direct technique used an Alexandrium-specific primary antibody coupled directly to magnetic beads, which were then bound to the target cells. With the indirect technique, the primary antibody (Ab) was bound to the target cells, and this Ab-cell complex was then exposed to the beads. Four different bead types, varying in size and coating, were evaluated. The bead isolation method was tested on live cells and on cells preserved with either $0.23 \mathrm{~N}$ sulfuric acid or $4 \%$ formalin. Under optimal conditions using either live or preserved cells, ca. $80 \%$ recovery was achieved when the indirect technique was applied with either M-280 Streptavidin or M-280 sheep anti-mouse beads. However, with the direct technique, the highest recoveries were only ca. $20 \%$ with live samples and ca. $50 \%$ with acidpreserved cells. After bead isolation, ca. $70 \%$ of the recovered live cells were intact; $30 \%$ were completely or partially broken. A variety of post-isolation measurements were conducted on the separated cells, including nucleic acids, total proteins, chlorophyll a (chl a), C-2 toxin, saxitoxin (STX), neosaxitoxin (NEO), organic carbon (C) and nitrogen $(\mathrm{N})$, and ${ }^{13} \mathrm{C} /{ }^{12} \mathrm{C}$ and ${ }^{15} \mathrm{~N} /{ }^{14} \mathrm{~N}$. These measurements were normalized to the number of intact cells. For live samples, there were no statistically significant differences between the control cells and the bead-recovered cells for cell quotas of nucleic acids, total proteins, chl a, STX, C-2 toxin, and NEO. Similarly, no differences were found in these parameters between the live samples and the acid-preserved samples, except for the nucleic acid measurements where the acid interfered with the measurements. However, there were significant differences between the live cells and formalin-preserved, bead-recovered cells for all parameters measured. This was not due to the bead isolation procedure but to the preservative. Significant $\mathrm{C}, \mathrm{N}, \mathrm{C} / \mathrm{N},{ }^{13} \mathrm{C} /{ }^{12} \mathrm{C}$, and ${ }^{15} \mathrm{~N} /{ }^{14} \mathrm{~N}$ differences between live cells and bead-recovered cells were introduced by the immunomagnetic separation protocols, due to the chemical and isotopic content of the beads. These artifacts need to be removed if monospecific elemental and isotopic abundance measurements are to be attempted using this isolation method. Overall, immunomagnetic cell sorting is potentially a valuable tool for taxon-specific isolation, allowing physiological, chemical, and isotopic characterization of naturally occurring phytoplankton populations. However, each measurement must be evaluated to insure that the cell components do not change due to the isolation procedure.
\end{abstract}

KEY WORDS: Alexandrium fundyense - Dinoflagellate $\cdot$ Immunomagnetic isolation · Magnetic beads · Saxitoxin $\cdot{ }^{14} \mathrm{C}$ uptake $\cdot$ Chlorophyll $\mathrm{a} \cdot \mathrm{DNA} \cdot \mathrm{RNA} \cdot{ }^{13} \mathrm{C} /{ }^{12} \mathrm{C} \cdot{ }^{15} \mathrm{~N} /{ }^{14} \mathrm{~N} \cdot$ Carbon $\cdot$ Nitrogen $\cdot$ Protein Resale or republication not permitted without written consent of the publisher

\section{INTRODUCTION}

Traditionally, studies measuring physiological parameters, chemical constituents, or isotopic ratios in aquatic ecosystems have treated the plankton community as a single, homogeneous entity. For example, biomass and primary production are among the most commonly measured parameters in biological oceano- 
graphy, yet conventional methods provide estimates averaged over the entire community in a water sample, and no information is provided on the distribution of production rates or biomass among taxa (Kemp et al. 1993). To understand the dynamics of the component organisms that make up that community, a methodology is needed that can provide sufficient biomass for species-specific physiological measurements.

A number of methods have attempted to separate individual cells from mixed plankton assemblages. For example, size fractionation of suspended particles using sieves has been used to separate natural populations and relate productivity to cell size (Anderson 1965, Furnas 1983, Probyn et al. 1990), but the method gives little, if any, taxonomic resolution (Lignell 1992). Manual microscopic isolation of cells (Rivkin \& Seliger 1981, Rivkin et al. 1984, Rivkin 1985, Graneli et al. 1997) has also been used for species-specific productivity measurements, but the method is slow and tedious. Autoradiography is used to estimate primary production rates of individual phytoplankton species (Watt 1971), but it is also tedious and difficult to quantify (Maguire \& Neill 1971, Stross \& Pemrick 1974). Flow cytometry can sort individual cells from a sample flow stream based on their unique fluorescent (either intrinsic or immunofluorescent) and light scattering properties (Chisholm et al. 1988, Olson et al. 1988). However, overlap between the size and fluorescence properties of target cells and non-target cells can make discrimination and separation of the desired species difficult (Anderson 1995, Vrieling \& Anderson 1996).

Another approach has been to separate and measure the chemical constituents of a population, not relying on whole cells. The separation of algal pigments by chromatography (Mantoura \& Llewellyn 1983, Gieskes \& Kraay 1986a,b) has allowed the contribution of different algal classes to total photosynthesis to be estimated through an assessment of the carbon-specific ${ }^{14} \mathrm{C}$ activity of taxon-specific pigments (Gieskes \& Kraay 1989). Since many species in the same algal class have similar pigment characteristics, this method cannot provide information on a single taxon, unless sorted prior to analysis or in the rare cases when blooms are monospecific. $\mathrm{C}$ and $\mathrm{N}$ elemental and stable isotopic natural abundances within individual species of phytoplankton may provide unique information about growth rates, physiology, nutrient sources, uptake pathways, and ambient environmental conditions (e.g. Wasser et al. 1998, Burkhardt et al. 1999, Laws et al. 2001). However, such characterization of natural phytoplankton populations has been hampered by the inability to isolate sufficient taxonspecific biomass for analysis. For unambiguous chemical measurements of phytoplankton populations, a practical means of isolating sufficient mono-specific biomass from natural waters is needed.

Recently, a method was developed to separate a single phytoplankton species from preserved seawater samples using magnetic beads and monoclonal antibodies raised against cell surface antigens (Aguilera et al. 1996). Although this methodology has been widely used in the medical field, such as in the isolation of cells (Brun et al. 1990, Vrendenburg \& Ball 1990, Vrendenburg et al. 1991), viruses, and organelles (Haukanes \& Kvam 1993), its use in phytoplankton studies is only beginning. Here, we evaluate immunomagnetic separation as a procedure for the isolation of live and preserved cells of the toxic dinoflagellate Alexandrium fundyense and determine the effects of such procedures on subsequent physiological and chemical analyses of the isolated populations.

\section{MATERIALS AND METHODS}

Cultures and field samples. Non-axenic, clonal cultures of Alexandrium fundyense Balech (GTCA29) were grown in $\mathrm{f} / 2$ medium (Guillard \& Ryther 1962) at $20^{\circ} \mathrm{C}$ on a $14: 10 \mathrm{~h}$ light:dark cycle (ca. $200 \mu \mathrm{E} \mathrm{m}^{-1} \mathrm{~s}^{-2}$, cool-white fluorescent bulbs). Field plankton samples were collected from Eel Pond (Woods Hole, MA) using a $20 \mu \mathrm{m}$ net. The natural seawater samples contained ca. 5 to $10 \times 10^{3}$ cells ml ${ }^{-1}$ with approximately $5 \%$ dinoflagellates, $70 \%$ diatoms and $25 \%$ other unidentified phytoplankton species. The samples were enriched with $5000 \pm 200$ cells of A. fundyense from culture to provide a target cell population within the samples. This spiking procedure allowed the physiological and chemical characteristics of those cells to be known, for comparative purposes with the beadrecovered cells.

Monoclonal antibodies. The monoclonal antibody (M8751-1) was developed against Alexandrium tamarense/catenella isolated from Japanese waters (Adachi et al. 1993a,b). It consistently exhibits specificity against other Alexandrium strains, including the GTCA29 strain isolated from the Gulf of Maine, USA (Adachi et al. 1993c), even when grown under different environmental conditions (Anderson et al 1999). The antibody has also been shown to react with natural field populations of Alexandrium from the Gulf of Maine (Turner et al. 2000, Townsend et al. 2001), while it does not crossreact significantly with other non-Alexandrium phytoplankton species or detritus contained in the field samples examined thus far.

Preparation of magnetic particles. Several different paramagnetic beads from Dynal Biotech were used: M-280 Streptavidin-coated Dynabeads (M-280 St; $2.8 \mu$ m diameter), M-280 sheep anti-mouse IgG (M-280 
$\mathrm{SaM}_{i} 2.8 \mu \mathrm{m}$ diameter), and the larger M-450 goat anti-mouse IgG Dynabeads (M-450 GaM; $4.5 \mu \mathrm{m}$ diameter). Slightly smaller (0.5 to $1.5 \mu \mathrm{m}$ diameter) BioMag streptavidin-coated beads (BioMag St) from PerSeptive Biosystems were also tested. Beads were supplied as a stock suspension containing ca. 4 to $7 \times$ $10^{8}$ beads $\mathrm{ml}^{-1}$ in $0.02 \mathrm{M}$ phosphate buffered saline (PBS, pH 7.4) containing 0.1\% Bovine Serum Albumin (BSA) and $0.02 \%$ sodium azide. To remove the sodium azide before use, an aliquot of beads was washed twice and then resuspended with $0.5 \mathrm{ml}$ of PBS, using the Dynal Magnetic Particle Concentrator (MPC-6) to collect the beads. Washed beads can be stored at $4^{\circ} \mathrm{C}$ for about 1 wk until use.

Isolation of target cells. The immunomagnetic bead protocols have been previously described in detail (Aguilera et al. 1996). Flow diagrams of the procedure are given there and are not repeated here. Briefly, in the direct approach, an antibody (Ab) specific for the target cell is first coupled to the magnetic beads, and this Ab-bead complex is used to capture the desired cells using the MPC-6 magnet, while unwanted cells not bound to the beads are washed away by successively resuspending the bead-cell complex out of the magnetic field and then recapturing the washed cells with the magnet. Alternatively, with the indirect technique, the primary $\mathrm{Ab}$ is first bound to the target cells, and then the beads coated with secondary Ab are added to the cell suspension. Again, the MPC-6 was used to magnetically capture, wash, and recapture the bead-cell complex.

Direct technique. When using streptavidin-coated beads (M-280 St and BioMag St) in the direct method, it was necessary to first bind biotin and then the specific $\mathrm{Ab}$ to the bead before treating the cells. Pre-washed streptavidin-coated beads $\left(6 \times 10^{6}\right.$ beads $500 \mu \mathrm{l}$ per sample) were incubated in microcentrifuge tubes with $200 \mu \mathrm{l}$ of biotin-conjugated goat anti-mouse secondary antiserum (GaM-biotin, B-7022, Sigma Chemical), diluted 1:150 with PBS for 30 min under constant mixing at room temperature on a Labquake Shaker (LabIndustries). The streptavidin-biotin bead complexes were collected by placing the test tubes in the MPC- 6 and washed 3 times with $1 \mathrm{ml}$ of PBS. With each wash, the beads were completely recaptured by the magnet within 2 to $3 \mathrm{~min}$. After the last wash, $500 \mu$ l of primary Ab (M8751-1), diluted 1:50 with 5\% (v/v) normal goat serum (NGS, G-9023, Sigma Chemical) was added and incubated for another $30 \mathrm{~min}$ on a Labquake shaker. Finally, the Ab-bead complexes were washed 3 times with $500 \mu$ l PBS using the MPC- 6 and resuspended in $500 \mu \mathrm{l}$ PBS. Negative control beads were incubated under the same conditions using mouse myeloma protein (MMP, M-9269, Sigma Chemical), diluted 1:100 with $5 \%$ NGS, instead of primary
Ab. The protein concentration of MMP approximated the specific $\mathrm{Ab}$ concentration of the monoclonal Ab.

Samples containing target Alexandrium fundyense populations (both live or fixed depending on the experiment) were washed once with $1 \mathrm{ml}$ of PBS by centrifugation $(3000 \times g$ for $3 \mathrm{~min})$ to remove seawater, incubated with $500 \mu \mathrm{l} 5 \%$ NGS for 30 min to block nonspecific binding, and washed again in $1 \mathrm{ml}$ PBS. The cells were then resuspended in $500 \mu \mathrm{l}$ of PBS and incubated with the Ab-activated beads for 30 min with constant mixing. Before incubation, a $100 \mu$ l aliquot of the sample was removed for cell counting to estimate the number of target cells present before bead attachment (see subsection 'Determination of recovery percentage' below). The target $A$. fundyense cells bound to the beads were then captured from the sample into a pellet against the wall of the tube using the MPC-6. After $10 \mathrm{~min}$ in the magnetic field, the pellet was gently washed 5 times in $1 \mathrm{ml}$ of PBS by successive resuspension and then recaptured with the magnet. All samples were finally resuspended in $500 \mu \mathrm{l}$ PBS, and aliquots of $100 \mu \mathrm{l}$ were removed for final counting to determine the percentage recovery of the target cells (see subsection 'Determination of recovery percentage' below).

When using either the M-280 SaM or M-450 GaM beads (which do not have a streptavadin coating), it was not necessary to coat the beads with biotin. In this case, the beads were incubated for $30 \mathrm{~min}$ with only the primary $\mathrm{Ab}$ to activate the beads, followed by a 30 min incubation with the target cells. Bovine serum albumin (BSA, A-6793, Sigma Chemical), diluted to a final concentration of $5 \%(\mathrm{w} / \mathrm{v})$ in PBS, was used as the blocking agent instead of $5 \%$ NGS. M-280 SaM and M-450 GaM bead concentrations were $6 \times 10^{6}$ and $4 \times$ $10^{6}$ per sample $(500 \mu \mathrm{l})$, respectively.

Indirect technique. Samples containing Alexandrium fundyense were washed by centrifugation once with $1 \mathrm{ml}$ PBS to remove the seawater and were blocked for 30 min with $500 \mu 15 \%$ NGS diluted in PBS. Cells were washed again with $1 \mathrm{ml}$ PBS, then incubated 30 min with $200 \mu$ l of a 1:50 dilution of the primary $\mathrm{Ab}$ in $5 \%$ NGS. After washing once with $1 \mathrm{ml}$ of PBS, the cells were biotinylated by adding $200 \mu \mathrm{l}$ of a 1:150 dilution of GaM-biotin secondary antiserum in PBS to the cell pellet and incubating for $30 \mathrm{~min}$ at room temperature. After 2 more washes in $1 \mathrm{ml}$ PBS, the biotinylated cell suspension was brought to a final volume of $500 \mu \mathrm{l}$. The secondary Ab step (i.e. biotinylation) was not necessary when using the M-450 GaM beads or the M-280 SaM beads.

To complete the cell isolation, an appropriate concentration of the pre-washed beads (ca. $6 \times 10^{6}$ beads per $500 \mu \mathrm{l}$ sample) was added to the Ab-labeled cells and incubated for $30 \mathrm{~min}$. Constant mixing in the 
Labquake Shaker was necessary to ensure efficient binding of the beads to the target cells. The target Alexandrium fundyense cells bound to the beads were then separated from the sample using an MPC-6 as in the direct technique above. The negative controls were incubated under the same conditions using MMP, diluted 1:100 with 5\% NGS, instead of the primary Ab.

Determination of recovery percentage. After $\mathrm{Ab}$ labeling, but before attachment to the beads, $100 \mu \mathrm{l}$ of each sample was removed and diluted to $500 \mu \mathrm{l}$. A minimum of 3 replicate counts of $100 \mu \mathrm{l}$ each were performed using a Palmer-Maloney counting chamber to estimate the number of target cells remaining just prior to attachment. For comparison, 3 subsamples of $100 \mu \mathrm{l}$ were removed for counting after attachment to the beads. The ratio of the latter number to the former was used to determine the percentage recovery of target cells. Note that this is not the same as the initial number of cells in the sample before any manipulation, as cell loss undoubtedly occurred (usually ca. 20 to $30 \%$ loss) in the washing steps prior to bead attachment. Statistical comparisons were made using Student's $t$-test to compare means among the different treatments.

Immunofluorescent techniques were used to facilitate the counting of the Alexandrium fundyense cells in natural seawater samples. The samples were first incubated with the M8751-1 primary $\mathrm{Ab}$ (1:50 in 0.1\% BSA) for $30 \mathrm{~min}$, washed 3 times with PBS in $0.1 \%$ BSA, followed by incubation with a secondary FITCconjugated goat anti-mouse Ab (F-0257, Sigma Chemical, 1:100 in $0.1 \% \mathrm{BSA}$ ) for $30 \mathrm{~min}$. If the target cells had already been exposed to the primary Ab (e.g. positive tests) during the isolation procedure, it was not necessary to add more primary Ab. All counts were enumerated using a Zeiss IM35 inverted epifluorescence microscope equipped with an FITC filter set (Zeiss filter set no. 487709; excitation filter-band pass 450 to $490 \mathrm{~nm}$ and emission filter-long pass $520 \mathrm{~nm}$ ).

Measurement of physiological parameters. ${ }^{14} \mathrm{C}$ uptake: Exponentially growing cultured cells of Alexandrium fundyense were transferred into $60 \mathrm{ml}$ Nalgene polycarbonate flasks. The contents of commercially prepared $1 \mathrm{ml}$ ampoules of $\mathrm{NaH}^{14} \mathrm{CO}_{3}$ containing $20 \mu \mathrm{Ci}$ (No. 17441S91; ICN Radiochemicals) were promptly added to each flask and mixed. Immediately, $0.1 \mathrm{ml}$ was removed to a liquid scintillation vial containing $200 \mu$ of hyamine hydroxide (Sigma) to estimate the total activity initially available for uptake. Samples were incubated at $20^{\circ} \mathrm{C}$ for $1 \mathrm{~h}$ in light (ca. $200 \mu \mathrm{E} \mathrm{m}^{-1} \mathrm{~s}^{-2}$ irradiance, cool-white fluorescent bulbs) and dark conditions. From each flask, 4 replicate $15 \mathrm{ml}$ aliquots containing ca. $1 \times 10^{4}$ cells were gently filtered (Nucleopore $0.8 \mu \mathrm{m}$ ) and rinsed 3 times with $20 \mathrm{ml}$ of PBS. Two filters were used as controls to determine total activity per cell before the cell isolation procedure. The remaining 2 filters were placed into $1.5 \mathrm{ml}$ microcentrifuge tubes and the cells were blocked with $5 \%$ NGS diluted in PBS for 30 min to prepare them for bead isolation.

During the blocking step, the tubes were repeatedly inverted on the Labquake shaker such that a sufficient number of cells for bead isolation were detached from the filter. The samples were centrifuged $(3000 \times g$ for $3 \mathrm{~min}$ ) and the magnetic bead procedure performed as above. The final pellets containing the beads and beads with attached target cells were transferred into $7 \mathrm{ml}$ borosilicate scintillation vials with $200 \mu \mathrm{l}$ of $20 \%$ $\mathrm{HCl}$. The open vials were placed in a ventilated fume hood overnight to remove all $\mathrm{HCl}$ vapors. Seven $\mathrm{ml}$ of ScintiVerse II (Fisher) scintillation cocktail were added to each vial (both the initial vials treated with hyamine hydroxide and the sample vials treated with $\mathrm{HCl}$ ). The activities were counted in a Beckman LS5000TD liquid scintillation spectrometer with the standard ${ }^{14} \mathrm{C}$ channel, using the external standards ratio method for quench correction.

In addition to the live cell treatment above, formalin (4\% final concentration), sulfuric acid $(0.23 \mathrm{~N}$ final) and glutaraldehyde $(0.5 \%$ final) were used as preservatives. The different preservatives were added at the end of the ${ }^{14} \mathrm{C}$ incubation and the cells were allowed to remain in the preservative for specified lengths of time $(0,30,60 \mathrm{~min}$, and 1 to $2 \mathrm{wk}$ intervals) before bead isolation.

DNA and RNA: DNA and RNA measurements were obtained using the CyQuant Cell Proliferation Assay Kit (C-7026; Molecular Probes) which uses CyQuant$\mathrm{GR}$, a dye that exhibits strong green fluorescence (excitation maximum $=480 \mathrm{~nm}$; emission maximum $=$ $520 \mathrm{~nm}$ ) when bound to nucleic acids. Exponentially growing Alexandrium fundyense cells (ca. $1 \times 10^{4}$ sam$\left.\mathrm{ple}^{-1}\right)$ were centrifuged $(3000 \times g$ for $3 \mathrm{~min})$ and isolated using magnetic beads. The final pellet of beads and recovered cells was diluted with the kit's lysis buffer, which contained $\mathrm{NaCl}(180 \mathrm{mM}), \mathrm{CaCl}_{2}$ $(100 \mathrm{mM})$, and $\mathrm{MgCl}_{2}(100 \mathrm{mM})$ in DEPC water. The cells were mechanically broken using a minibeadbeater (Biospec Products).

DNA and RNA contents of the samples were determined by measuring the remaining DNA after RNase treatment and the remaining RNA after DNase treatment. Subtraction from the total nucleic acid content yielded measurements for DNA and for RNA. For each sample, four $100 \mu \mathrm{l}$ aliquots of the supernatant were placed in a 96-well tissue culture plate (Costar 3596). One well was not treated with the enzymes for determination of total DNA + RNA. One well was treated with $1.1 \mu$ of RNase (1.35 Kunitz units $\mathrm{ml}^{-1}$ final concentration), while another was treated with $3 \mu \mathrm{l}$ of 
DNase (90 Kunitz units $\mathrm{ml}^{-1}$ final concentration). In the remaining well, both enzymes were added as a negative control. The plate was incubated for $1 \mathrm{~h}$ at $37^{\circ} \mathrm{C}$. One hundred $\mu \mathrm{l}$ of the CyQuant-GR dye-diluted in cell lysis buffer was added and incubated for $5 \mathrm{~min}$ at room temperature. The green fluorescence from the dye was quantified with a CytoFluor 2300 fluorescence microtiter plate reader (Millipore) using a $485 \pm 20 \mathrm{~nm}$ filter for excitation and a $530 \pm 25 \mathrm{~nm}$ filter for emission.

Total proteins: To lyse the cells for total protein measurement, cell pellets (with or without beads attached) were diluted in $1 \mathrm{ml}$ of PBS containing 10\% SDS, Leupeptin (10 $\mathrm{gg} \mathrm{ml}^{-1}, \mathrm{~L} 2884$ Sigma) and Pepstatin A (10 $\mathrm{g} \mathrm{m} \mathrm{ml}^{-1}$, P5318 Sigma). The cells were broken using the mini-beadbeater and the lysates were recovered and incubated for $1 \mathrm{~h}$ on ice. Protein was determined spectroscopically using standard procedures for the BCA Protein Assay Reagent (Pierce). Bovine serum albumin was used as the protein standard.

Chlorophyll a analysis: Chlorophyll a (chl a) was extracted in $90 \%$ acetone using procedures described by Johnsen \& Sakshaug (1993). Concentrations were estimated fluorometrically using a Turner Designs Model 10-AU fluorometer (Strickland \& Parsons 1972).

Toxin analysis: Toxins were extracted from the Alexandrium fundyense cells in a sample using $200 \mu \mathrm{l}$ of $0.05 \mathrm{M}$ acetic acid added to each pellet. Samples were sonicated and centrifuged $(3000 \times g$ for $5 \mathrm{~min})$ prior to transfer into 1.5 teflon capped borosilicate autoanalyzer vials. The toxins were analyzed by HPLC using the modified method of Oshima et al. (1989) described by Anderson et al. (1994). All toxin experiments were performed with unpreserved cells only.

Carbon and nitrogen elemental and stable isotopic analyses: The carbon $(\mathrm{C})$ and nitrogen $(\mathrm{N})$ content and associated ${ }^{13} \mathrm{C} /{ }^{12} \mathrm{C}$ and ${ }^{15} \mathrm{~N} /{ }^{14} \mathrm{~N}$ were determined on replicate samples of cultured Alexandrium fundyense cells (ca. $2 \times 10^{5} \pm 10^{4}$ cells per sample), cells bound to the $\mathrm{Ab}$ (ca. $1.2 \times 10^{5} \pm 10^{4}$ cells per sample), and cells treated with the Ab and the Dynal M-280 St beads (ca. $1.1 \times$ $10^{5} \pm 10^{4}$ cells per sample). Replicate samples from each of these treatments were filtered onto pre-combusted, $25 \mathrm{~mm}$ Whatman GF/F filters, as were untreated $30 \mu \mathrm{l}$ Dynal bead suspensions. For comparison to the latter, untreated $100 \mu$ l BioMag St bead suspensions were also analyzed. These samples, together with filter blanks, were dried and stored dry prior to analysis. Each filter was subsequently saturated with a $10 \%$ solution of $\mathrm{HCl}$ to remove inorganic $\mathrm{C}$, re-dried, combusted, and the resultant $\mathrm{CO}_{2}$ and $\mathrm{N}_{2}$ yields measured and isotopically analyzed as described by Rau et al. (1990). By convention, isotopic ratios in a sample are reported as the per $\mathrm{ml}$ relative difference between the sample and a standard:

$$
\delta X=1000\left(R_{\text {sample }}-R_{\text {standard }}\right) / R_{\text {standard, }} \%
$$

where $X={ }^{13} \mathrm{C}$ or ${ }^{15} \mathrm{~N}, R={ }^{13} \mathrm{C} /{ }^{12} \mathrm{C}$ or ${ }^{15} \mathrm{~N} /{ }^{14} \mathrm{~N}$ and standard $=$ PDB carbonate or air $\mathrm{N}_{2}$, respectively. The precision of mass spectrometric analysis for a given gas sample $\delta^{13} \mathrm{C}$ or $\delta^{15} \mathrm{~N}$ is typically \pm 0.2 or $\pm 0.3 \%$, respectively.

\section{RESULTS}

\section{Microscopic observations}

With the bead treatment using live samples, $70 \%$ of the recovered Alexandrium fundyense cells retained their shape, although all cells lost their flagella. The remaining $30 \%$ were completely or partially broken, whereas in the preserved samples, all cells generally maintained their integrity. In experiments where centrifugation was necessary to harvest live 'control' cells (i.e. cells prior to bead treatment), there was loss of flagella but no broken cells. After incubation in fresh f/2 medium for several days, some of the recovered live cells lost the attached beads and were freely swimming. There were differences between live and preserved cells in the number of attached beads. In live samples, the number of attached beads per cell was low (ca. 10 beads per cell), whereas with preserved cells, the attached beads were usually impossible to count due to their high number.

\section{Cell recovery in live and acid-preserved samples}

Sulfuric acid (0.23 N), sometimes used in ${ }^{14} \mathrm{C}$ productivity experiments (Riemann \& Moller 1991, Taylor \& Howes 1994), was tested and compared to live cells as a possible preservative prior to bead isolation. Using the direct technique with live cells (Fig. 1A), the percent recovery of Alexandrium fundyense was low$<30 \%$ in all bead treatments. However, using the indirect technique with live cells (Fig. 1B), the recovery was much higher (ca. 80 and $70 \%$ with either the M-280 St or the M-280 SaM beads, respectively). Recovery of target cells was $<20 \%$ when M-450 GaM or BioMag St beads were tested with the indirect technique. When no primary $\mathrm{Ab}$ was present (i.e. negative controls), the recovery was $<10 \%$ in all treatments.

The results were slightly different when acidpreserved samples were isolated. Using the direct technique (Fig. 2A), the percent recoveries for the M-280 St and M-280 SaM were higher than for live cell treatments (Fig. 1A), reaching ca. 50 and $45 \%$, respectively. As with the live cell treatments, the recovery of acid-preserved Alexandrium fundyense cells was $<20 \%$ when M-450 GaM or BioMag St beads were used. The best recovery was observed using the indi- 

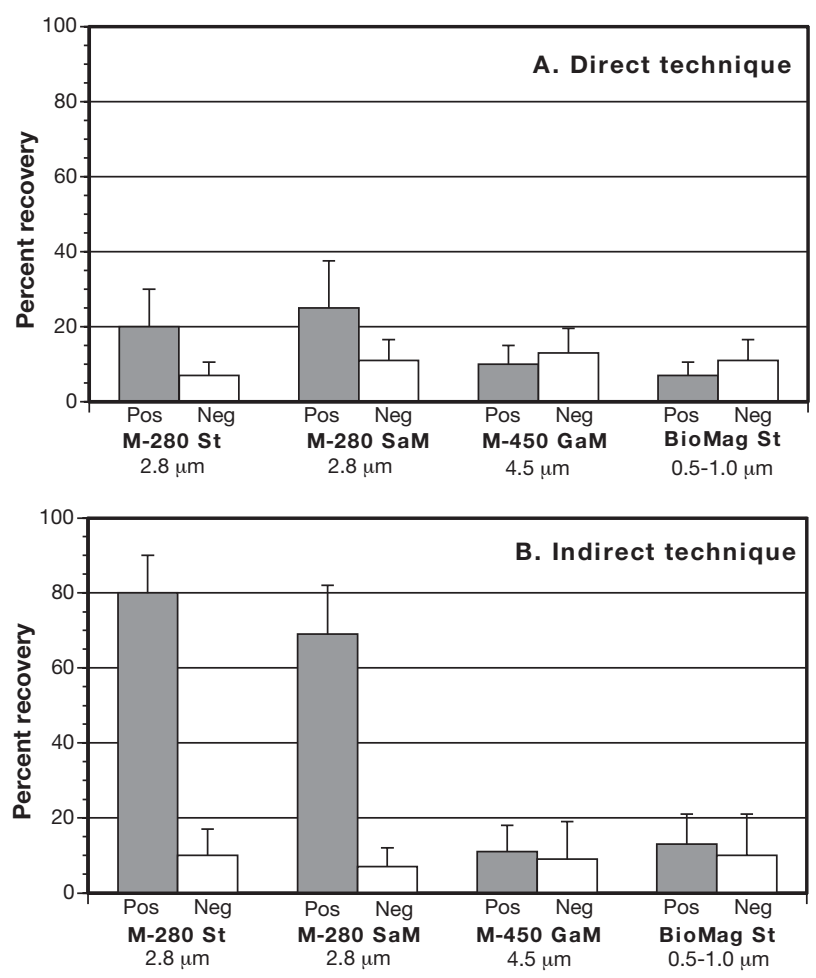

Fig. 1. Recovery of live cultured Alexandrium fundyense cells added to concentrated field samples. Two isolation protocols were used: (A) direct technique and (B) indirect technique. Pos: positive labeling with primary antibody present; Neg: negative controls with primary antibody omitted. Error bars represent $\pm 1 \mathrm{SD}$ for each treatment

rect technique to isolate the acid-preserved target cells (Fig. 2B), reaching ca. $80 \%$ for both the M-280 St and the M-280 SaM beads. The percentages for the M-450 GaM and BioMag St beads remained around 20\% when the indirect technique was used. The negative controls were $<15 \%$ in all experiments.

To determine the optimal storage time for acidpreserved samples, a time course experiment was performed (Fig. 3). Bead isolations of the acid-preserved cells were performed after 0,30 , and $60 \mathrm{~min}, 1$ to $2 \mathrm{~d}$, and 1 to 2 wk of preservation. Approximately 60 to $80 \%$ of the cells were recovered during the shorter preservation times $(0,30,60 \mathrm{~min}$, and 1 to $2 \mathrm{~d})$ and no statistical differences $(p>0.05)$ were found among treatments. When the cells were stored for a longer period (1 to $2 \mathrm{wk}$ ) in acid at $4^{\circ} \mathrm{C}$, the percent recovery decreased to ca. $50 \%$, but this decline was not significant ( $p>0.05)$. In all treatments, $<15 \%$ of the target cells were recovered in the negative controls without primary Ab.

The minimum number of final washes needed to remove non-target cells from bead-isolated target cells was evaluated as well. In the first 2 washes, nearly $30 \%$ of the unbound cells were eliminated (data not shown), while the next 2 additional washes removed another
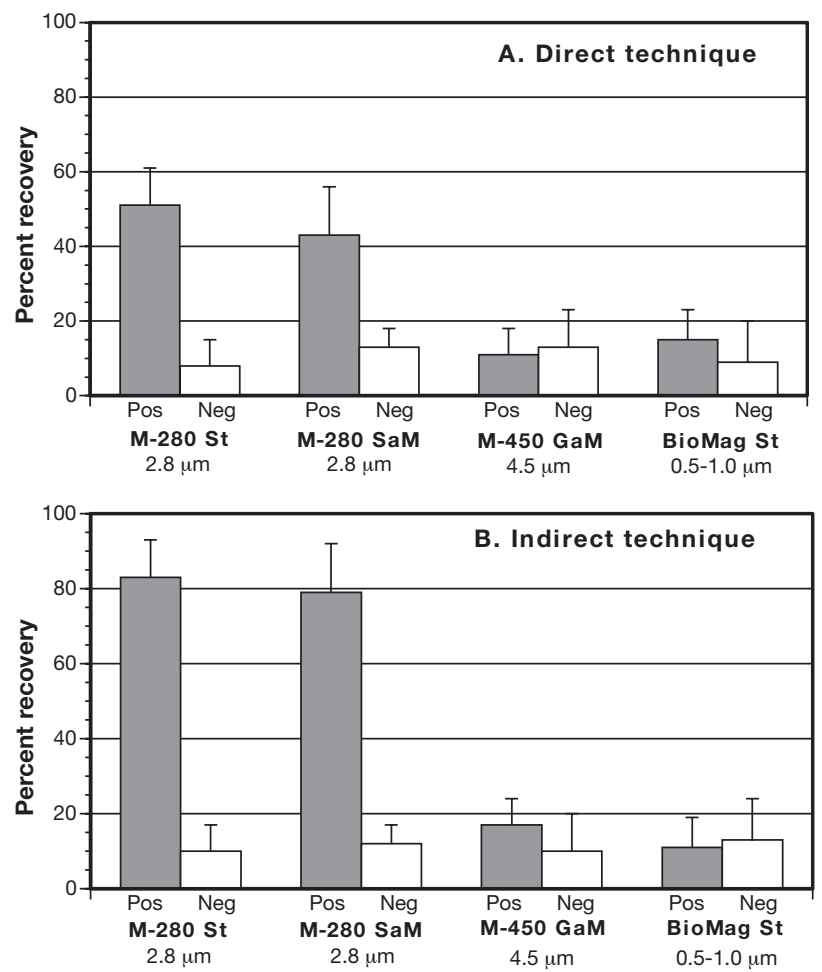

Fig. 2. Recovery of sulfuric acid-preserved cultured Alexandrium fundyense cells added to concentrated field samples. Two isolation protocols were used: (A) direct technique and (B) indirect technique. Pos: positive labeling with primary antibody present; Neg: negative controls with primary antibody omitted. Error bars represent \pm 1 SD for each treatment

$60 \%$ of the unbound cells. Subsequent washings only removed an additional $1 \%$ of the unbound cells. These increases in the number of washes did not significantly reduce the recovery percentages of target cells. Consequently, 5 washes were used for all experiments.

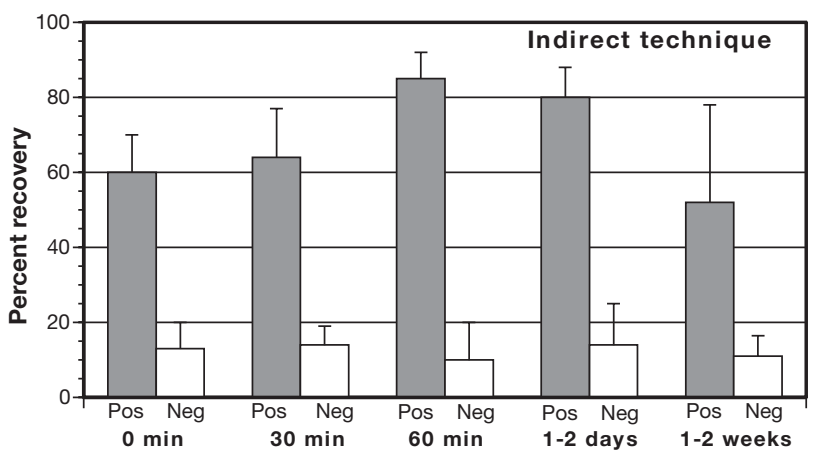

Fig. 3. Effect of the storage time on the percent recovery of sulfuric acid-preserved cultured Alexandrium fundyense cells added to concentrated field samples using the indirect technique and the M-280 Streptavidin beads. Pos: positive labeling with primary antibody present; Neg: negative controls with primary antibody omitted. Error bars represent $\pm 1 \mathrm{SD}$ for each treatment 


\section{${ }^{14} \mathrm{C}$ uptake measurements}

The ${ }^{14} \mathrm{C}$ uptake rate for unpreserved control cells (without bead treatment) was ca. $250 \pm 60 \mathrm{pg} \mathrm{cell}^{-1} \mathrm{~h}^{-1}$ (Fig. 4). When the unpreserved cells were isolated with either M-280 St or M-280 SaM beads, the uptake rates were slightly lower, but not significantly ( $p>0.05)$. For the acid-preserved treatments (Fig. 4A), the uptake rates of the preserved cells without bead isolation compared to uptake rates of the preserved cells after bead isolation were also not significantly different $(p>0.05)$, regardless of which bead type was used for the isolation. Furthermore, when the cells were preserved with sulfuric acid for $<1,30$, and $60 \mathrm{~min}$, the ${ }^{14} \mathrm{C}$ uptake rates were not significantly different from the live, unpreserved control cells. When the incubated samples were preserved for 1 to $2 \mathrm{wk}$ in acid before bead isolation, the ${ }^{14} \mathrm{C}$ uptake rate was lower than in the unpreserved control (ca. 160 vs $250 \mathrm{pg} \mathrm{cell}^{-1} \mathrm{~h}^{-1}$ ), but this difference was not significant ( $p>0.05$ ). In every case, cells isolated with the M-280 St beads exhibited slightly higher uptake rates than the M-280 SaM beads and were generally closer to the values found for the unpreserved treatments.
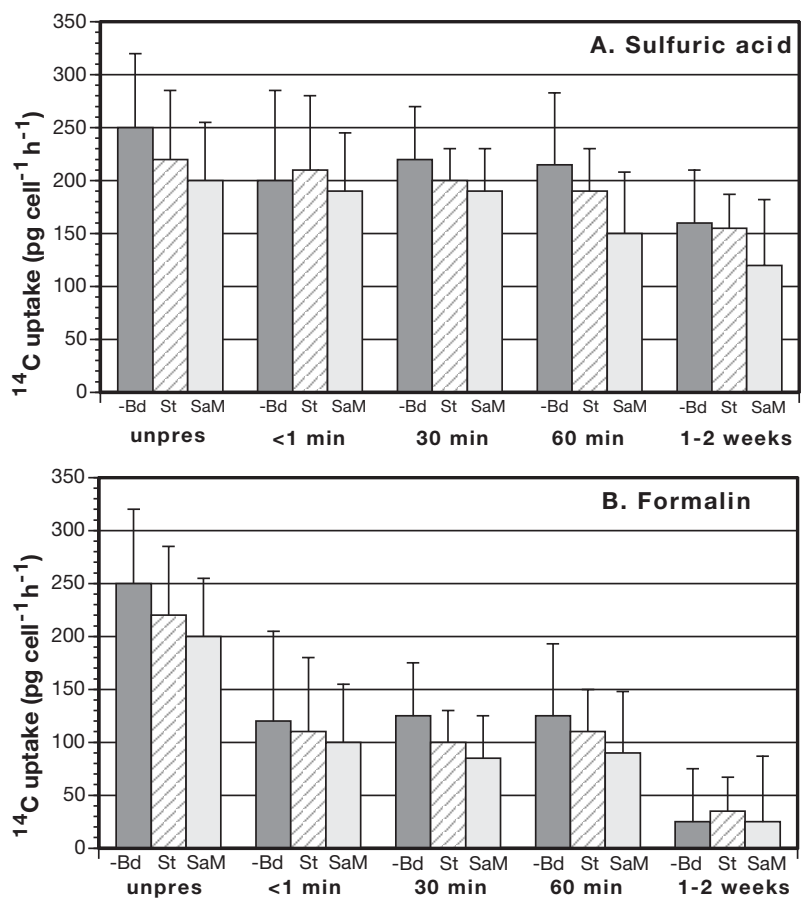

Fig. 4. Time series of ${ }^{14} \mathrm{C}$ uptake rates at different preservation times and after the isolation using indirect technique and cultured Alexandrium fundyense cells. (A) unpreserved controls and sulfuric acid-preserved cells; (B) unpreserved controls and formalin-preserved cells. unpres: no preservative used; $-\mathrm{Bd}$ : cells without bead treatment; St: cells after bead isolation with M-280 Streptavidin beads; SaM: cells after bead isolation with M-280 SaM beads. Error bars represent $\pm 1 \mathrm{SD}$ for each treatment
When cells were preserved with formalin (Fig. 4B), ${ }^{14} \mathrm{C}$ uptakes rates were significantly lower (ca. $125 \pm$ $\left.50 \mathrm{pg} \mathrm{cell}^{-1} \mathrm{~h}^{-1} ; \mathrm{p}<0.05\right)$ than those of the unpreserved cells, even with little exposure to the formalin ( $<1 \mathrm{~min})$. The loss of activity was most notable when the samples were preserved for 1 to $2 \mathrm{wk}$.

\section{DNA and RNA determinations}

DNA content was ca. $270 \pm 50 \mathrm{ng}$ cell $^{-1}$ for unpreserved control samples not isolated with beads (Fig. 5A). No significant differences were found between the DNA content of these cells and that of cells after the bead treatment $(p>0.05)$ with either type of bead. The use of sulfuric acid or formalin preservatives, however, reduced DNA levels to $<50 \mathrm{ng}$ cell $^{-1}$, even in the controls without bead treatment (Fig. 5A).

Similar results were obtained when RNA was measured (Fig. 5B). Unpreserved control cells without bead treatment had an average RNA content of ca. $62 \pm 10 \mathrm{ng}$ cell $^{-1}$, which was not statistically different ( $p>0.05$ ) from the amount measured in unpreserved
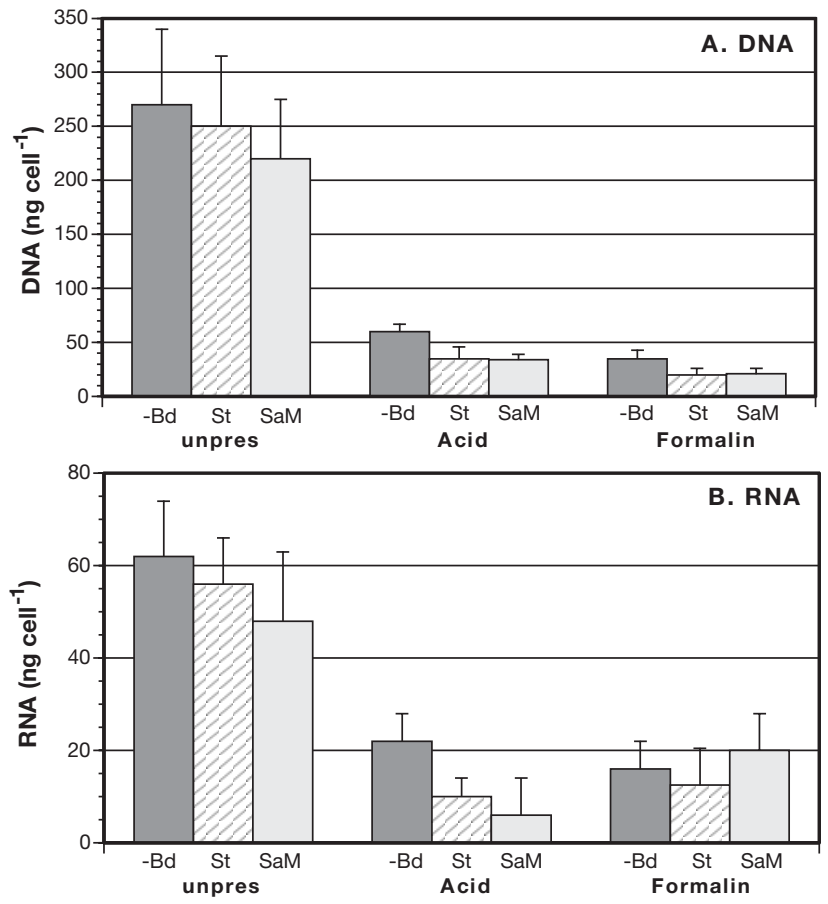

Fig. 5. Total amount of nucleic acids per cell after the isolation using the indirect technique and cultured Alexandrium fundyense cells. (A) DNA amounts in unpreserved controls, acid- and formalin-preserved treatments; (B) RNA amounts in unpreserved controls, acid- and formalin-preserved treatments. unpres: no preservative used; - Bd: cells without bead treatment; St: cells after bead isolation with M-280 Streptavidin beads; SaM: cells after bead isolation with M-280 SaM beads. Error bars represent \pm 1 SD for each treatment 
cells isolated with beads. When the acid or formalin preservatives were used, RNA content decreased significantly to $<20 \mathrm{ng} \mathrm{cell}^{-1}$ for all the treatments.

\section{Total protein determinations}

Mean total protein concentration was ca. $6.4 \pm 0.8 \mathrm{ng}$ cell $^{-1}$ in unpreserved cell lysates without bead treatment (Fig. 6). Similar amounts were present ( $p>0.05$ ) after bead isolations of unpreserved cells using either of the 2 bead types. Acid-preserved cells showed no significant protein losses $(p>0.05)$ compared to unpreserved control cells (ca. $6.0 \pm 1.0$ and $6.4 \mathrm{ng} \mathrm{cell}{ }^{-1}$, respectively), even when treated with beads. However, when $4 \%$ formalin was used as the preservative, protein content decreased to ca. $1.5 \pm 0.4 \mathrm{ng} \mathrm{cell}^{-1}$ for all 3 experimental conditions.

\section{Chlorophyll a}

The chl a content in the unpreserved controls was ca. $23 \pm 5 \mathrm{pg} \mathrm{cell}^{-1}$ without bead treatment. Using either the M-280 St or M-280 SaM bead types, the concentration was statistically the same ( $p>0.05$, Fig. 7). For cells preserved in sulfuric acid for short times (Fig. 7A), the chl a concentration was statistically the same as the control for the $<1,30$, and $60 \mathrm{~min}$ treatments $(\mathrm{p}>0.05)$, regardless of bead type. However, when samples were preserved in acid for 1 to $2 \mathrm{wk}$, chl a cell ${ }^{-1}$ was significantly lower (ca. 10 pg cell $^{-1}, \mathrm{p}<0.05$ ) compared to unpreserved control samples. Formalin-preserved cells, with or without bead treatment, had significantly lower chl a cell ${ }^{-1}$ than did the unpreserved control samples ( $p<0.05$, Fig. 7B).

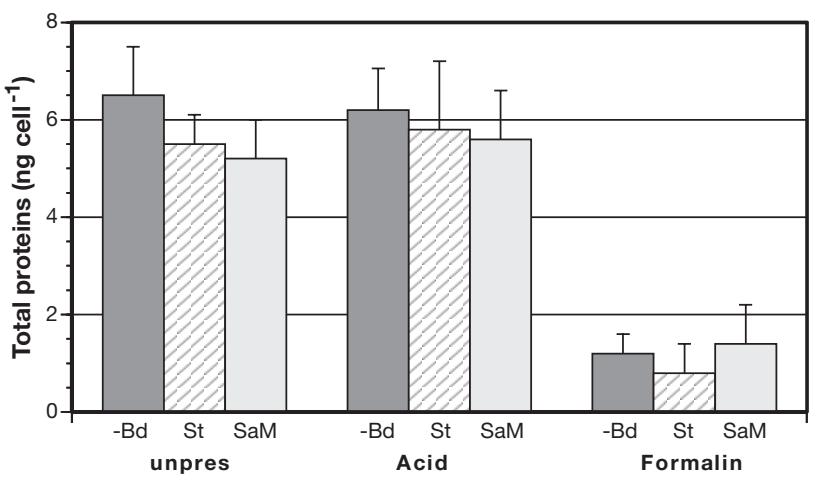

Fig. 6. Total amount of protein per cell in unpreserved and preserved cultured Alexandrium fundyense cells after isolation using the indirect technique. unpres: no preservative used; $-B d$ : control cells without bead treatment; St: cells after bead isolation with M-280 Streptavidin beads; SaM: cells after bead isolation with M-280 SaM beads. Error bars represent $\pm 1 \mathrm{SD}$ for each treatment
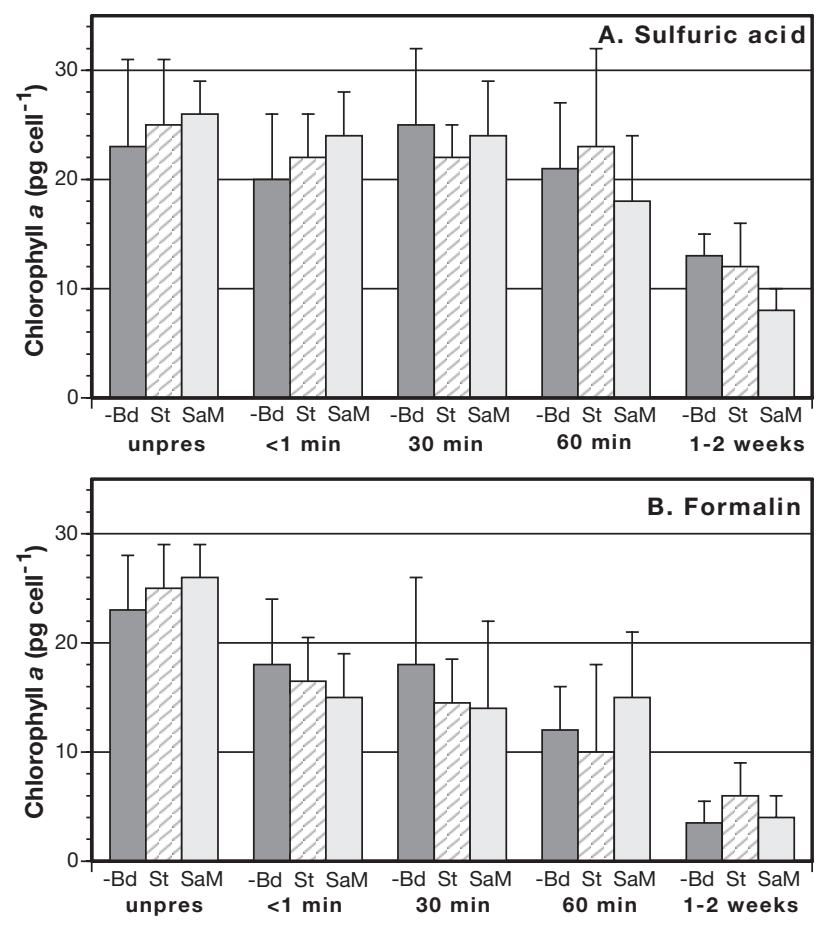

Fig. 7. Chl a concentration per cell after bead isolation using the indirect technique and cultured Alexandrium fundyense cells. (A) Unpreserved controls and sulfuric acid-preserved treatments; (B) unpreserved controls and formalin-preserved treatments. unpres: no preservative used; $-\mathrm{Bd}$ : control cells without bead treatment; St: cells after bead isolation with M-280 Streptavidin beads; SaM: cells after bead isolation with M-280 SaM beads. Error bars represent \pm 1 SD for each treatment

Longer-term exposure to the formalin $(<1,30,60 \mathrm{~min}$, and 1 to $2 \mathrm{wk}$ ) led to greater declines.

\section{Toxin content}

The concentrations of C-2, neosaxitoxin (NEO), and saxitoxin (STX) in unpreserved samples without bead treatment were $19.0 \pm 1.5,61 \pm 4$, and $6.0 \pm 1.9 \mathrm{fmol}$ cell $^{-1}$, respectively (Fig. 8). Samples after the bead treatment had $20 \%$ less C-2 toxin than cells without bead treatment, but this was not statistically significant $(p>0.05)$. Likewise, there were no significant differences $(p>0.05)$ in the NEO or STX measurements between the cells without bead treatment and the bead-isolated cells.

\section{Carbon and nitrogen elemental and isotopic composition}

Untreated blank filters yielded on average $2.0 \mu \mathrm{mol}$ $\mathrm{C}$ and $0.2 \mu \mathrm{mol} \mathrm{N}$ per filter (Table 1). These yields 


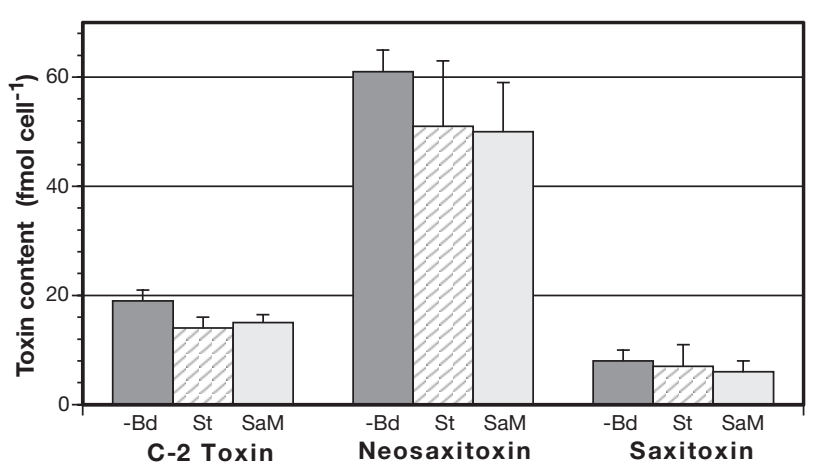

Fig. 8. Toxin content per cell after bead isolation using the indirect technique and unpreserved, cultured Alexandrium fundyense cells. - Bd: control cells without bead treatment; St: cells after bead isolation with M-280 Streptavidin beads; SaM: cells after bead isolation with M-280 SaM beads. Error bars represent \pm 1 SD for each treatment

were usually small relative to the treatment filters, but were used to filter-blank-correct the following treatment results. The following trend was observed in $\mathrm{C}$ yields per cell: cells $+\mathrm{Ab}+$ beads $>$ cells $>$ cells $+\mathrm{Ab}$ (Table 1). $\mathrm{N}$ cell ${ }^{-1}$ relationships were: cells $>$ cells $+\mathrm{Ab}+$ beads $>$ cells $+\mathrm{Ab}$. The following $\mathrm{C} / \mathrm{N}$ relationships pertain: cells $+\mathrm{Ab}+$ beads $>$ cells $+\mathrm{Ab}$ $>$ cells (Table 1). The Dynal bead-only analyses on average yielded $17.4 \mu \mathrm{mol} \mathrm{C}$ and $1.2 \mathrm{umol} \mathrm{N}$ per $30 \mu \mathrm{l}$ of bead suspension with a resultant mean $\mathrm{C} / \mathrm{N}$ of 14.6 .
Mean blank filter $\delta^{13} \mathrm{C}$ and $\delta^{15} \mathrm{~N}$ were $-24.8 \pm 0.1$ and $9.0 \pm 0.3 \%$, respectively, and were used to filter-blankcorrect the treatment isotope data listed in Table 1. The relationships for both $\delta^{13} \mathrm{C}$ and $\delta^{15} \mathrm{~N}$ among treatments were as follows: cells $>$ cells $+\mathrm{Ab} \gg$ cells $+\mathrm{Ab}+$ beads $>$ beads.

\section{DISCUSSION}

The use of magnetic beads to isolate target cells is common in biomedical research, but this technique has rarely been applied in aquatic systems. In previous studies (Aguilera et al. 1996, Costas \& Lopez-Rodas 1996), formalin-preserved Alexandrium cells were successfully isolated from natural samples using immunomagnetic beads. Target cells were efficiently recovered from samples, with $<5 \%$ contamination by other species. This method was deemed unlikely to be useful in cell enumeration, however, due to the loss of cells during the numerous washing steps, where ca. $50 \%$ of the total population may be lost. Since the cells that are recovered are 'clean' with respect to the presence of other taxa or detritus, a useful application of the method would be to measure species-specific physiological and chemical parameters. To achieve this, it was necessary to develop a method for the isolation of live and/or preserved cells in such a way that the treatments did not affect the measurements. Here, we demonstrate that live or carefully preserved

Table 1. $\mathrm{C}$ and $\mathrm{N}$ elemental and isotopic abundances in the samples indicated. Bead and Alexandrium fundyense results are filter-blank-corrected

\begin{tabular}{|c|c|c|c|c|c|c|c|c|}
\hline \multirow{2}{*}{$\begin{array}{l}\text { Sample/treatment } \\
\text { description }\end{array}$} & \multirow{2}{*}{$\begin{array}{l}\text { Total } \\
\text { cells }\end{array}$} & \multicolumn{7}{|c|}{ - Treatment means $( \pm \mathrm{SD})$} \\
\hline & & $\begin{array}{l}\text { C yield } \\
(\mu \mathrm{mol})\end{array}$ & $\begin{array}{c}\text { C cell }{ }^{-1} \\
\left(\mu \mathrm{mol} \mathrm{cell}{ }^{-1}\right)\end{array}$ & $\begin{array}{l}\text { N yield } \\
(\mu \mathrm{mol})\end{array}$ & $\begin{array}{c}\mathrm{N} \mathrm{cell}^{-1} \\
\left(\mu \mathrm{mol} \mathrm{cell}{ }^{-1}\right)\end{array}$ & $\begin{array}{c}\mathrm{C} / \mathrm{N} \\
(\mu \mathrm{mol} / \mu \mathrm{mol})\end{array}$ & $\begin{array}{l}\delta^{13} \mathrm{C} \\
(\% \circ)\end{array}$ & $\begin{array}{l}\delta^{15} \mathrm{~N} \\
(\%)\end{array}$ \\
\hline \multicolumn{9}{|l|}{ Filter-blank } \\
\hline Whatman GF/F & - & 2.0 & - & 0.2 & - & 12.4 & -24.8 & 9.0 \\
\hline Precombusted 25 mm & & $(-)$ & & $(-)$ & & $(-)$ & $( \pm 0.1)$ & $( \pm 0.3)$ \\
\hline \multicolumn{9}{|l|}{ Beads } \\
\hline Dynal M-280 St & - & 17.4 & - & 1.2 & - & 14.6 & -26.6 & -7.7 \\
\hline Streptavidin beads, $30 \mu \mathrm{l}$ & & $( \pm 0.6)$ & & $(< \pm 0.1)$ & & $(< \pm 0.1)$ & $( \pm 0.5)$ & $( \pm 1.2)$ \\
\hline $\begin{array}{l}\text { BioMag St beads, } 100 \mu \mathrm{l} \\
\text { (not used in treatments be }\end{array}$ & w) & $\begin{array}{c}7.1 \\
( \pm 0.2)\end{array}$ & - & $\begin{array}{c}1.9 \\
( \pm 0.4)\end{array}$ & - & $\begin{array}{c}3.7 \\
( \pm 1.0)\end{array}$ & $\begin{array}{l}-12.8 \\
( \pm 0.0)\end{array}$ & $\begin{array}{c}5.3 \\
( \pm 0.1)\end{array}$ \\
\hline \multicolumn{9}{|l|}{ Alexandrium fundyense } \\
\hline Cells & $2.0 \times 10^{5} \pm 10^{4}$ & $\begin{array}{c}32.4 \\
( \pm 0.1)\end{array}$ & $1.6 \times 10^{-4}$ & $\begin{array}{c}5.5 \\
( \pm 0.8)\end{array}$ & $2.7 \times 10^{-5}$ & $\begin{array}{c}6.2 \\
( \pm 1.3)\end{array}$ & $\begin{array}{l}-17.8 \\
( \pm 0.1)\end{array}$ & $\begin{array}{c}0.5 \\
( \pm 0.3)\end{array}$ \\
\hline Cells + antibody & $1.2 \times 10^{5} \pm 10^{4}$ & $\begin{array}{c}12.5 \\
( \pm 0.2)\end{array}$ & $1.0 \times 10^{-4}$ & $\begin{array}{c}1.4 \\
( \pm 0.1)\end{array}$ & $1.2 \times 10^{-5}$ & $\begin{array}{c}8.5 \\
( \pm 0.4)\end{array}$ & $\begin{array}{l}-18.8 \\
( \pm 0.2)\end{array}$ & $\begin{array}{l}-0.2 \\
( \pm 0.4)\end{array}$ \\
\hline Cells + antibody + beads & $1.1 \times 10^{5} \pm 10^{4}$ & $\begin{array}{c}28.2 \\
(< \pm 0.1)\end{array}$ & $2.6 \times 10^{-4}$ & $\begin{array}{c}2.6 \\
( \pm 0.1)\end{array}$ & $2.4 \times 10^{-5}$ & $\begin{array}{l}10.6 \\
( \pm 0.5)\end{array}$ & $\begin{array}{l}-23.3 \\
( \pm 0.1)\end{array}$ & $\begin{array}{l}-3.6 \\
( \pm 0.3)\end{array}$ \\
\hline
\end{tabular}


Alexandrium fundyense cells can be isolated with at least 85 to $90 \%$ purity. Although the isolated cells were not sufficiently viable to maintain a 'live' population for further experimentation, they were sufficiently numerous and intact for measurements of a suite of physiological parameters. Some of those measurements were statistically the same as for cells that had not been bead-recovered (e.g. ${ }^{14} \mathrm{C}$ uptake using short-term acid preservation, total protein, chl $a$, or toxin cell $^{-1}$ ). Other measurements did, however, show significant differences (e.g. ${ }^{14} \mathrm{C}$ uptake with formalin preservation). The method thus shows significant promise for cell isolation and analysis of phytoplankton populations, but each measurement must be evaluated for the species of interest to insure that cell components do not change during processing.

\section{Practical issues}

The number of cells required for a particular assay will depend primarily on the detection limit of that assay and the concentration of the parameter to be measured. Sensitive assays using isotopes may require $<100$ cells, while elemental analysis (e.g. CHN) may require as many as $10^{5}$ cells. Alexandrium concentrations during blooms range from 100s to 1000 s of cells $\mathrm{l}^{-1}$. This species often is not the dominant organism in a field sample, therefore it is necessary to concentrate field samples into smaller volumes using sieving (retaining the $>20 \mu \mathrm{m}$ fraction), centrifugation, and/or filtration to attain about 5000 cells - the number we used in most analyses. However, if higher cell numbers are needed, non-target cells might become overly concentrated and the immunomagnetic separation may require larger, more dilute volumes utilizing more beads. Even under the best conditions, a low level of contamination (10 to $15 \%$ based on recoveries of control samples) by non-target organisms occurs. For many purposes, this may be acceptable, however, given the importance of species-specific measurements and the lack of alternative approaches.

\section{Washes}

Since live cells are more fragile than formalinpreserved cells, the original isolation protocol (Aguilera et al. 1996) was modified by reducing the number of washes between each step in the Ab labeling and bead attachment processes. A change from 3 washes to only 1 led to a slight decrease in the percentage of target cells recovered, but it also dramatically decreased the number of broken cells present in the samples. It was necessary, however, to use 5 final washes to ensure that unbound cells were removed and the isolates were as pure as possible. The lowest non-specific recoveries $(<5 \%)$ were reported using formalin preservation (Aguliera et al. 1996), but as shown here, formalin was not acceptable as a preservative for essentially all physiological measurements. Attempts to reduce nonspecific binding further using blocking agents (e.g. BSA) have not been successful (Aguilera et al. 1996).

Another change was that the incubation time for bead-cell attachment was increased from 15 to $30 \mathrm{~min}$. Although longer incubation times did not increase the percentage of recovery when cells were formalinpreserved (Aguilera et al. 1996), we found that at least 30 min of incubation of the cells with the beads were necessary to obtain the best recoveries with live samples.

\section{Direct versus indirect labeling}

The choice between the direct and indirect technique had a significant effect on removal success. The best recoveries with live cells were obtained using the indirect technique, where ca. $80 \%$ of the cells were recovered, compared to $<30 \%$ using the direct approach. We had expected the direct technique to be the most useful for quantitative analysis of live cells, since the lower number of washing steps would, presumably, minimize cell losses. However, inefficient Ab binding offset any washing benefits. The indirect technique is more effective because free Ab can coat the surface antigens of a cell more effectively than $\mathrm{Ab}$ that are linked to beads, as is the case in the direct technique (Lea et al. 1990). The indirect technique is also recommended when using cocktails of monoclonal Ab or when targeting cells with low surface antigen density (Haukanes \& Kvam 1993).

\section{Bead coating}

Bead coating is another important factor affecting recovery of live cells. The number of target cells recovered using M-280 Streptavidin beads was about $10 \%$ higher than that obtained with M-280 SaM beads (Fig. 1B). The high specificity and affinity of the reaction between biotin and streptavidin is advantageous, although the use of streptavidin beads requires an extra step in the protocol (i.e. the biotinylization of the target cells). This extra step does not, however, cause significant deterioration in the physiological condition of the recovered cells. The low-percent recovery of cells in the negative controls (without primary $\mathrm{Ab}$ ) were similar for the 2 types of beads, which suggests that non-specific binding was more dependent on the blocking agent than on the bead coatings. 


\section{Bead size}

The size of the beads was also critical. The best recoveries were obtained with the $2.8 \mu \mathrm{m}$ bead types (M280 Streptavidin and M-280 SaM beads). When larger $(4.5 \mu \mathrm{m})$ beads (M-450 GaM) were used, the number of recovered cells dropped to $<20 \%$. Although the larger beads are commonly used in magnetic isolations of mammalian cells with recovery $>90 \%$, the results with Alexandrium fundyense were very poor even when experimental conditions were varied (data not shown). These results, which are similar to the earlier report for formalin-preserved A. fundyense cells (Aguilera et al. 1996), can be attributed to the increased surface area of the smaller beads yielding a higher number of Ab-binding sites per $g$ of beads. However, beads can be too small, as seen with the low recoveries obtained when BioMag St beads (0.5 to $1.5 \mu \mathrm{m})$ were used. Sufficient iron (magnetic mass) per attached cell is necessary to pull the cells toward the magnet. If the attraction is too weak, then target cells will be removed with the washes. Preliminary results using different bead sizes to isolate Pseudonitzschia pungens, a toxic diatom, indicated that the smaller BioMag St beads were the most effective, and better than the 2.8 or $4.5 \mu \mathrm{m}$ Dynal beads, and independent of bead coating (unpubl. data). Thus, for any given target species, it is necessary to screen a variety of bead types, coatings, and sizes to determine the best protocols.

\section{Preservatives and physiological measurements}

The fixative, or lack thereof, is an important consideration for bead isolations of target cells, and the choice is largely dependent on the physiological parameter that one intends to measure. Preservatives such as formaldehyde and glutaraldehyde are commonly used to prevent cell distortion, autolysis, and microbial activity, as well as to aid in retention of structural features during the storage and manipulation of the samples (Stoward 1973). They bind proteins and partially fix nucleic acids, but generally do not react with polysaccharides and lipids (Dawes 1971). In developing methods to measure physiological parameters, in particular primary productivity, preservatives like formalin have been widely reported to cause significant leakage of ${ }^{14} \mathrm{C}$ from labeled algal cells (Lean \& Burnison 1979, Li \& Goldman 1981, Goldman \& Dennett 1985, Hilmer \& Bate 1989, Lignell 1992). Our results agreed with these studies, as formalin was found to be an inadequate preservative not only for ${ }^{14} \mathrm{C}$ measurements (Fig. 4B), but also for DNA and RNA measurements (Fig. 5), total proteins (Fig. 6), and chl a (Fig. 7B). In all cases, there were significant losses between the live controls and the preserved samples that were not due to the bead treatment but rather to the preservative. These losses reflect either the cross-linking of the biomolecules (e.g. proteins and nucleic acids) rendering them difficult to detect, or membrane perforation that allows cell contents to leak into the medium (e.g. $\left.{ }^{14} \mathrm{C}\right)$.

Leakage problems can be avoided when net primary productivity is measured on acidified whole samples (Schlinder et al. 1972). Under the best experimental conditions, $>80 \%$ of the Alexandrium fundyense cells preserved in acid were recovered (Fig. 3), with excellent retention of cell integrity. However, longer-term storage in acid not only resulted in lower cell recoveries (Fig. 3), but it also caused greater losses of ${ }^{14} \mathrm{C} \mathrm{cell}^{-1}$ (Fig. 4A). At the conclusion of ${ }^{14} \mathrm{C}$ incubation, acid must be added immediately to terminate the uptake process, keeping the cells intact while releasing unincorporated ${ }^{14} \mathrm{CO}_{2}$. Thereafter, bead isolation has to begin within 60 min to insure the best results (Fig. 4A).

$\mathrm{Chl} a$, an indicator of phytoplankton biomass, is one of the most common parameters measured in aquatic ecosystems and is frequently used to normalize other measurements, e.g. ${ }^{14} \mathrm{C}$ uptake rate/chl a. The chl a cell $^{-1}$ values measured here on the unpreserved and short-term acid-preserved samples (either with or without bead treatment) generally agreed with controls and with values reported by Anderson et al. (1990) for the same species (Fig. 7). However, it does appear that the chl a method is quite sensitive to preservation with formalin or long-term storage with acid. This is not surprising since acid $(10 \% \mathrm{HCl})$ is used to degrade chl a to phaeopigments using standard methods (Strickland \& Parsons 1972). The degradation of $\mathrm{chl} a$ in the presence of acid is rapid (min) in cell extracts, but the results (Fig. 7) show that for Alexandrium fundyense whole cell isolations, the procedure can be initiated within $1 \mathrm{~h}$ of the addition of acid without significant chl a losses.

If chl $a$ is expressed per cell, based on the number of cells isolated, it can be used as an indicator of physiological status, such as nutrient or light limitation. However, further method development is needed to reduce cell losses before a species-specific chl a method can be used as an indicator of biomass in the field. We are currently exploring the use of the Photosystem II inhibitor, DCMU [3-(3,4-dichlorophenyl)-1,1-dimethyl urea], before or after bead isolation to provide an indication of photosynthetic efficiency that can complement measurements of chl a content.

Acid preservation was also suitable for determination of proteins (Fig. 6) and again, our bead-concentrated measurements agreed with controls and with values reported previously for pure cultures of Alexandrium sp. (Anderson et al. 1990). However, the nucleic acid measurements were not successful following acid 
preservation. Overall, our results suggest that shortterm preservation in sulfuric acid is the best procedure tested to date for the measurement of most, but not all, physiological parameters. In cases where acid fixation is not suitable, e.g. nucleic acids, unpreserved cells can still be measured, albeit on fewer cells due to some cell breakage during the processing.

\section{Elemental and isotopic effects}

It is evident from the variations in $\mathrm{C}$ and $\mathrm{N}$ yields per cell, C/N, and stable isotope abundances among cell treatments (Table 1) that the addition of antibodies and beads significantly modifies these values compared to untreated cells. This is not unanticipated since antibodies and beads can be expected to contribute foreign $\mathrm{C}$ and $\mathrm{N}$ to the treatment, and hence increase the $\mathrm{C}$ and $\mathrm{N}$ yields per cell. For example, Dynal bead C/N was significantly elevated and $\delta^{13} \mathrm{C}$ and $\delta^{15} \mathrm{~N}$ significantly depressed relative to Alexandrium fundyense cells. Measurements of cell treatments containing beads were accordingly modified by the presence of bead $\mathrm{C}$ and $\mathrm{N}$ (Table 1). BioMag St bead $\mathrm{C} / \mathrm{N}$, and isotopic abundances differed drastically from those of Dynal beads (Table 1). Use of the former beads would yield elemental and isotopic effects very different from those experienced with Dynal beads.

While pure $\mathrm{Ab} C, \mathrm{~N}$, and isotope abundances were not determined, it is evident by comparison between the cells and cells $+\mathrm{Ab}$ results that treatments containing $\mathrm{Ab}$ also depressed $\delta^{13} \mathrm{C}$ and $\delta^{15} \mathrm{~N}$ and elevated C/N. Curiously, the addition of Ab did not also increase $\mathrm{C}$ and $\mathrm{N}$ yield per cell, suggesting that cell $\mathrm{C}$ and $\mathrm{N}$ may have been lost in these treatments, perhaps due to cell breakage. Otherwise, based on the results of the cell-only treatments $\left(\mathrm{C} \mathrm{cell}{ }^{-1}=1.6 \times 10^{-4} \mu \mathrm{mol}_{;} \mathrm{N} \mathrm{cell}^{-1}=2.7 \times\right.$ $10^{-5} \mu \mathrm{mol}$; Table 1 ), the $1.2 \times 10^{5}$ cells harvested in the cells + Ab treatments would be expected to yield at least $6.7 \mu \mathrm{mol}$ more $\mathrm{C}$ and $1.8 \mu \mathrm{mol}$ more $\mathrm{N}$ than what was actually measured (Table 1 ). The $\mathrm{N}$ yields in the cells + $\mathrm{Ab}+$ beads treatments were also lower than expected based on treatment cell counts and the cells-only $\mathrm{N} \mathrm{cell}^{-1}$ results. We cannot exclude the possibility that the cell incubation, washing, and handing procedures themselves contributed to the elemental and isotopic differences observed in the $\mathrm{Ab}$ and bead treatments.

The preceding results indicate that there are significant elemental and isotopic artifacts introduced by the immunomagnetic cell separations described here. Future use of such methods to characterize monospecific $C, N$, and isotopic natural abundances will need to effectively account for or remove such effects (e.g. via appropriate procedural blanks and Ab/bead detachment from the cells).

\section{SUMMARY}

Our results suggest that it is possible to separate live or preserved unialgal subsamples from a mixed natural seawater sample and measure their physiological condition after that isolation. The utility of the procedure is enhanced by the fact that the isolation protocol and the presence of the beads do not interfere with a number of important physiological analyses. In cases where the beads interfere with a measurement, bead detachment protocols will need to be developed. Additional studies using $\mathrm{Ab}$ probes for a variety of other algal species are needed to extend its application, and further work is needed to determine whether other physiological measurements are possible. Immunomagnetic cell sorting has the potential to become a reliable complement to standard methods currently used in phytoplankton studies, especially for autecologists focusing on single species.

Acknowledgements. We thank Y. Ishida and Y. Sako for generously providing antibody M8751-1. We also thank C. Taylor, D. M. Kulis and G. Taroncher for their help in the ${ }^{14} \mathrm{C}$ uptake measurements as well as in the toxin analysis. G.H.R. acknowledges: (1) the assistance of C. Low and D. Des Marais in conducting elemental and isotopic abundance measurements at NASA-Ames Research Center; and (2) support from California Sea Grant (R/CZ-134) and the US NSF (OCE9618626). This research was supported by Spanish Ministerio de Educación y Ciencia fellowship AP9451384765 (to A.A.). This work is the result of research sponsored by the NOAA National Sea Grant College Program Office, Department of Commerce, under Grant No. NA46RG0470, Woods Hole Oceanographic Institution Sea Grant Project Nos. R/B-148-PT and R/B-140. This work was also supported by the US ECOHAB Program, sponsored by NOAA, NSF, EPA, NASA, and ONR; NOAA Grant NA960P0099 and NSF Grant OCE9808173. The US Government is authorized to produce and distribute reprints for governmental purposes notwithstanding any copyright notation that may appear hereon. Contribution No. 32 of the US ECOHAB Program and Contribution No. 10550 of the Woods Hole Oceanographic Institution.

\section{LITERATURE CITED}

Adachi M, Sako Y, Ishida Y (1993a) The identification of conspecific dinoflagellates $A$. tamarense from Japan and Thailand by monoclonal antibodies. Nippon Suisan Gakkaishi 59(2):327-332

Adachi M, Sako Y, Ishida Y (1993b) Application of monoclonal antibodies to field samples of Alexandrium species. Nippon Suisan Gakkaishi 59:1171-1175

Adachi M, Sako Y, Ishida Y, Anderson DM, Reguera B (1993c) Cross-reactivity of five monoclonal antibodies to various isolates of Alexandrium as determined by an indirect immunofluorescence method. Nippon Suisan Gakkaishi 59:1807

Aguilera A, Gonzalez-Gil S, Keafer BA, Anderson DM (1996) Immunomagnetic separation of cells of the toxic dinoflagellate $A$. fundyense from natural plankton samples. Mar Ecol Prog Ser 143:255-269 
Anderson DM (1995) Identification of harmful algal species using molecular probes: an emerging technology. In: Lassus P, Arzul G, Erard E, Gentien P, Marcaillou C (eds) Harmful marine algal blooms. Lavoiser Science Publishers, Paris, p 3-13

Anderson DM, Kulis DM, Sullivan JJ, Hall S, Lee C (1990) Dynamics and physiology of saxitoxin production by the dinoflagellates Alexandrium spp. Mar Biol 104:511-524

Anderson DM, Kulis DM, Doucette GJ, Gallagher JC, Balech E (1994) Biogeography of toxic dinoflagellates in the genus Alexandrium from the northeastern United States and Canada. Mar Biol 120:467-478

Anderson DM, Kulis DM, Keafer BA, Berdelet E (1999) Detection of the toxic dinoflagellate Alexandrium fundyense (Dinophyceae) with oligonucleotide and antibody probes: variability in labeling intensity with physiological condition. J Phycol 35:870-883

Anderson GC (1965) Fractionation of phytoplankton communities off the Washington and Oregon coasts. Limnol Oceanogr 10:477-480

Brun A, Gaudernack G, Sandberg S (1990) A new method for isolation of reticulocytes: positive selection of human reticulocytes by immunomagnetic separation. Blood 76(11): 2397-2403

Burkhardt S, Zondervan I, Riebesell U (1999) Effect of $\mathrm{CO}_{2}$ concentration on $\mathrm{C}: \mathrm{N}: \mathrm{P}$ ratio in marine phytoplankton: a species comparison. Limnol Oceanogr 44:683-690

Chisholm SW, Olson RJ, Zettler ER, Goericke R, Waterbury JB, Welschmeyer NA (1988) A novel free-living prochlorophyte abundant in the oceanic euphotic zone. Nature 334: 340-343

Costas E, Lopez-Rhodas V (1996) Enumeration and separation of the toxic dinoflagellate Alexandrium minutum from natural samples using immunological procedures with blocking antibodies. J Exp Mar Biol Ecol 198:81-87

Dawes CJ (1971) Biological techniques in electron microscopy. International textbook series. Barnes and Noble, New York

Furnas MJ (1983) Nitrogen dynamics in lower Narragansett Bay, Rhode Island: approaches to measurement, community and species growth rates. J Plankton Res 12: $1117-1151$

Gieskes WW, Kraay GW (1986a) Floristic and physiological differences between the shallow and the deep nanophytoplankton community in the euphotic zone of the open Tropical Atlantic revealed by HPLC analysis of pigments. Mar Biol 91:567-576

Gieskes WW, Kraay GW (1986b) Analysis of phytoplankton pigments by HPLC before, during and after mass occurrence of the microflagellate Corymbellus aureus during the spring bloom in the open northern North Sea in 1983. Mar Biol 92:45-52

Gieskes WW, Kraay GW (1989) Estimating the carbonspecific growth rate of the major algal species group in eastern Indonesian waters by ${ }^{14} \mathrm{C}$ labeling of taxonspecific carotenoids. Deep-Sea Res 36:1127-1139

Goldman JC, Dennett MR (1985) Susceptibility of some marine phytoplankton species to cell breakage during filtration and post-filtration rinsing. J Exp Mar Biol Ecol $86: 47-58$

Graneli E, Anderson DM, Carlsson P, Maestrini SY (1997) Light and dark carbon uptake by Dinophysis-species in comparison to photosynthetic and heterotrophic dinoflagelates. Aquat Microb Ecol 13:177-186

Guillard RR, Ryther JH (1962) Studies of marine plankton diatoms. 1. Cyclotella nana Hustedt and Detonula confervacea (Cleve.). Can J Microbiol 8:229-239
Haukanes B, Kvam C (1993) Application of magnetic beads in bioassays. Bio/Technology 11:60-63

Hilmer T, Bate GC (1989) Filter types, filtration and postfiltration treatment in phytoplankton production studies. J Plankton Res 11:49-63

Johnsen G, Sakshaug E (1993) Bio-optical characteristics and photoadaptive responses in the toxic and bloom-forming dinoflagellates Gyrodinium aureolum, Gymnodinium galatheanum, and two strains of Prorocentrum minimum. J Phycol 29:627-642

Joint IR (1986) Physiological ecology of picoplankton in various oceanographic provinces. In: Platt T, Li WKW (eds) Photosynthetic picoplankton. Can Bull Fish Aquat Sci 214: 289-309

Kemp PF, Lee S, LaRoche J (1993) Estimating the growth rate of slowly growing marine bacteria from RNA content. Appl Environ Microbiol 59:2594-2601

Laws EA, Popp BN, Bidigare RR, Riebesell U, Burkhardt S, Wakeham SG (2001) Controls on the molecular distribution and carbon isotopic composition of alkenones in certain haptophyte algae. Geochem Geophys Geosyst 2 (available at: www.g-cubed.org; Paper No., 2000GC000057)

Lea T, O'Connell JP, Nustad K, Funderud S, Berge A, Rembaum A (1990) Microspheres as immunoreagents for cell identification and cell fractionation. In: Helameds $\mathrm{MR}_{\text {, }}$ Lindmo T, Mendelsohn M (eds) Flow cytometry and sorting. Wiley-Liss, New York, p 367-380

Lean DRS, Burnison BK (1979) An evaluation of errors in the ${ }^{14} \mathrm{C}$ method of primary production measurement. Limnol Oceanogr 24:917-928

Li WK, Goldman JC (1981) Problems in estimating growth rates of marine phytoplankton from short-term ${ }^{14} \mathrm{C}$ assays. Microbiol Ecol 7:113-121

Lignell $\mathrm{R}$ (1992) Problems in filtration fractionation of ${ }^{14} \mathrm{C}$ primary productivity samples. Limnol Oceanogr 37 : 172-178

Maguire B Jr, Neill WE (1971) Species and individual productivity in phytoplankton communities. Ecology 52:903-907

Mantoura RFC, Llewellyn CA (1983) The rapid determination of algal chlorophyll and carotenoid pigments and their breakdown products in natural waters by reverse-phase high-performance liquid chromatography. Anal Chim Acta 151:297-314

Olson RJ, Chisholm SW, Zettler ER, Armburst EV (1988) Analysis of Synechococcus pigment types in the sea using single and double beam flow cytometry. Deep-Sea Res 35: 425-440

Oshima YS, Sugino K, Yasumoto T (1989) Latest advances in HPLC analysis of paralytic shellfish toxins. In: Natori $\mathrm{S}_{\text {, }}$ Hashimoto K, Ueno Y (eds) Mycotoxins and phycotoxins '88. Proc 7th Int IUPAC Symp, Elsevier, Amsterdam p 319-326

Probyn TA, Waldron HN, James AG (1990) Size-fractionated measurements of nitrogen uptake in aged upwelled waters: implication for pelagic food webs. Limnol Oceanogr 33:202-211

Rau GH, Teyssie JL, Rassoulzadegan R, Fowler SW (1990) ${ }^{13} \mathrm{C} /{ }^{12} \mathrm{C}$ and ${ }^{15} \mathrm{~N} /{ }^{14} \mathrm{~N}$ variations among size-fractionated marine particles: implications for their origin and trophic relationships. Mar Ecol Prog Ser 59:33-38

Riemann B, Moller L (1991) Measurements of phytoplankton primary production by means of the acidification and bubbling method. J Plankton Res 13:853-862

Rivkin RB (1985) Carbon-14 labeling patterns of individual marine phytoplankton from natural populations. Mar Biol 89:135-142

Rivkin RB, Seliger HH (1981) Liquid scintillation counting for 
${ }^{14} \mathrm{C}$ uptake of single algal cells isolated from natural samples. Limnol Oceanogr 26:780-784

Rivkin RB, Swift E, Biggley WH, Voytek MA (1984) Growth and carbon uptake by natural populations of Pyrocystis noctiluca and Pyrocytis fusiformis. Deep-Sea Res 31:353-367

Schlinder DW, Schmidt RV, Reid RA (1972) Acidification and bubbling as an alternative to filtration in determining phytoplankton production by the ${ }^{14} \mathrm{C}$ method. J Fish Res Board Can 29:1627-1631

Stoward PJ (1973) Fixation in histochemistry. Chapman \& Hall, London

Strickland JD, Parsons TR (1972) A practical handbook of seawater analysis. Bull Fish Res Board Can Bull 167:201-203

Stross RG, Pemrick SM (1974) Nutrient uptake kinetics in phytoplankton: A basis for niche separation. J Phycol 10: 164-169

Taylor CD, Howes BL (1994) Effect of sampling frequency on measurements of seasonal primary production and oxygen status in near-shore coastal ecosystems. Mar Ecol Prog Ser 108:193-203

Townsend DW, Pettigrew NR, Thomas AC (2001) Offshore blooms of the red tide dinoflagallate, Alexandrium sp., in the Gulf of Maine. Cont Shelf Res 21:347-369

Editorial responsibility: Diane Stoecker (Contributing Editor), Cambridge, Maryland, USA
Turner JT, Doucette GJ, Powell CL, Kulis DM, Keafer BA, Anderson DM (2000) Accumulation of red tide toxins in larger size fractions of zooplankton assemblages from Massachusetts Bay, USA. Mar Ecol Prog Ser 203:95-107

Vrendenburg JJ, Ball ED (1990) Elimination of small cell carcinoma of the lung from human bone narrow by monoclonal antibodies and immunomagnetic beads. Cancer Res 50:7216-7220

Vrenderburg JJ, Simpson W, Memoli VA, Ball ED (1991) Reactivity of anti-Cd ${ }^{15}$ monoclonal antibody PM-81 with breast cancer and elimination of breast cancer cells from human bone marrow by PM-81 and immunomagnetic beads. Cancer Res 51:2451-2455

Vrieling EG, Anderson DM (1996) Immunofluorescence in phytoplankton research: applications and potential. J Phycol 32:1-6

Wasser NAD, Turpin DH, Harrison PJ, Nielsen B, Calvert SE (1998) Nitrogen isotope fractionation during the uptake and assimilation of nitrate, nitrite, ammonium and urea by a marine diatom. Limnol Oceanogr 43:215-224

Watt WD (1971) Measuring the primary production rates of individual phytoplankkton species in natural mixed populations. Deep-Sea Res 18:329-339

Submitted: January 7, 2000; Accepted: November 19, 2001 Proofs received from author(s): June 21, 2002 